\title{
Overlooked Role of Sulfur-Centered Radicals During Bromate Reduction by Sulfite
}

Junlian Qiao ${ }^{\mathrm{a}, \mathrm{b}, \mathrm{c}}$, Liying Feng ${ }^{\mathrm{a}}$, Hongyu Dong ${ }^{\mathrm{a}}$, Zhiwei Zhao ${ }^{\mathrm{d}}$, Xiaohong Guan ${ }^{\mathrm{a}, \mathrm{b}, \mathrm{c}^{*}}$

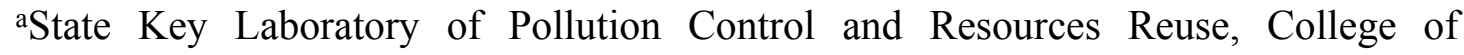
Environmental Science and Engineering, Tongji University, Shanghai 200092, P.R. China

bShanghai Institute of Pollution Control and Ecological Security, Shanghai 200092, P.R.

China

'International Joint Research Center for Sustainable Urban Water System, Tongji University, Shanghai 200092, P.R. China

${ }^{\mathrm{d}}$ Key Laboratory of the Three Gorges Reservoir Region's Eco-Environment, State Ministry of Education, Chongqing University, Chongqing 400045, China

*Author to whom correspondence should be addressed

Xiaohong Guan, email: guanxh@tongji.edu.cn; phone: +86-21-65983869; Fax: +86$21-65986313$

Totally 25 pages including 4 Texts, 3 Tables, and 15 Figures. 


\section{Text S1. Chemicals and Reagents}

Sodium bromate $\left(\mathrm{NaBrO}_{3}\right)$, sodium bromide $(\mathrm{NaBr})$, bromine $\left(\mathrm{Br}_{2}\right)$, sodium bisulfite $\left(\mathrm{NaHSO}_{3}\right)$, tert-Butanol (TBA), ethanol (EtOH), phenol, acetaminophen (ACT), bisphenol A (BPA), carbamazepine (CBZ), atrazine (ATZ), benzoic acid (BA), nitrobenzene (NB), disodium hydrogen phosphate $\left(\mathrm{Na}_{2} \mathrm{HPO}_{4}\right)$, hydrogen peroxide $\left(\mathrm{H}_{2} \mathrm{O}_{2}\right)$, silver nitrate $\left(\mathrm{AgNO}_{3}\right)$, normal hexane, 2,4-dinitrophenylhydrazine (DNPH), and sulfuric acid $\left(\mathrm{H}_{2} \mathrm{SO}_{4}\right)$ were purchased from Sinopharm Chemical Reagent Co., Ltd. (Shanghai, China). Ethylenediaminetetraacetic acid disodium salt (EDTA-2Na) and sodium dihydrogen phosphate $\left(\mathrm{NaH}_{2} \mathrm{PO}_{4}\right)$ were bought from Jiangsu Qiangsheng Chemical Reagent Co., Ltd. (Changshu, China). 5,5'-dithiobis (2-nitrobenzoic acid) (DTNB) and norfloxacin (NOR) were obtained from Aladdin Biological Technology Co., Ltd. (Shanghai, China). Sodium thiosulfate pentahydrate $\left(\mathrm{Na}_{2} \mathrm{~S}_{2} \mathrm{O}_{3} \cdot 5 \mathrm{H}_{2} \mathrm{O}\right)$ and sodium hydroxide $(\mathrm{NaOH})$ were supplied by the Tianjin Chemical Reagent Co., Ltd. (Tianjin, China). 5,5-dimethyl-1-pyrrolidine-N-oxide (DMPO) was purchased from Dojindo Laboratory. Methanol and formic acid of chromatographic grade were supplied by Avantor Performance Materials, Inc. (USA). HOBr solution was prepared following the reported method: Brown-red solutions of $\mathrm{Br}_{2}$ were titrated with $\mathrm{AgNO}_{3}$ solution in an ice bath to the colorless endpoint and then filtered. ${ }^{1}$ The stock solutions of $\mathrm{HOBr}$ and $\mathrm{NaHSO}_{3}$ were freshly prepared for each set of experiments. All chemicals were used as received and all solutions were prepared in deionized water $(>18.2$ $\mathrm{M} \Omega \cdot \mathrm{cm}$ resistivity; Millipore Milli-Q system).

\section{Text S2. Experimental Procedures for Organic Contaminants Degradation, Quenching Experiments, and Formaldehyde Formation}

To examine the degradation of various organic contaminants during $\mathrm{BrO}_{3}{ }^{-}$ reduction by sulfite, the experiments were initiated by adding $\mathrm{NaHSO}_{3}$ stock solution 
into a mixed solution containing organic contaminants and $\mathrm{BrO}_{3}^{-}$at desirable concentrations. An exact amount of sample $(5.0 \mathrm{~mL})$ was periodically withdrawn and quenched by $100 \mu \mathrm{L} \mathrm{Na} \mathrm{S}_{2} \mathrm{O}_{3} \cdot 5 \mathrm{H}_{2} \mathrm{O}$ stock solution $(250 \mathrm{mM})$, then filtered through $0.22 \mu \mathrm{m}$ filters before quantified with ultra-performance liquid chromatography (UPLC). Quenching experiments were conducted in reaction solutions amended with ethanol (EtOH) or tertbutyl alcohol (TBA) as radical scavenger to assess their potential influence on the reaction kinetics. In addition, formaldehyde, the product of methanol oxidation by radicals, was quantified to further examine the generation of radicals in $\mathrm{BrO}_{3}{ }^{-} /$sulfite process.

\section{Text S3. Analytical Methods}

The concentrations of $\mathrm{BrO}_{3}^{-}$and $\mathrm{Br}^{-}$were determined with an IC (Dionex ICS5000, Thermo Fisher Scientific) equipped with a conductivity detector (Dionex ACES 300, Thermo Fisher Scientific), an analytical column (AS19, $2 \times 250 \mathrm{~mm}$, Thermo Fisher Scientific), and a guard column (AG19, $2 \times 50 \mathrm{~mm}$, Thermo Fisher Scientific). The mobile phase was a $30 \mathrm{mM} \mathrm{KOH}$ aqueous solution at a flow rate of $0.2 \mathrm{~mL} / \mathrm{min}$. The temperatures of the conductivity detector and column were $35{ }^{\circ} \mathrm{C}$ and $30{ }^{\circ} \mathrm{C}$, respectively. Under these conditions, the detection limit was $1.0 \mu \mathrm{g} / \mathrm{L}$ for both $\mathrm{BrO}_{3}{ }^{-}$ and $\mathrm{Br}^{-}$when the injection volume was $500 \mu \mathrm{L}$.

The concentrations of phenol, acetaminophen (ACT), bisphenol A (BPA), carbamazepine (CBZ), atrazine (ATZ), benzoic acid (BA), nitrobenzene (NB), and norfloxacin (NOR) were quantified with UPLC (ACQUITY UPLC H-Class, Waters). The compounds were separated with a BEH C18 column $(2.1 \times 100 \mathrm{~mm}, 1.7 \mu \mathrm{m}$, Waters) in an isocratic mode of elution at $35 \pm 1{ }^{\circ} \mathrm{C}$ with $\mathrm{UV}$-visible detector. Other details of the analysis conditions are provided in Table S1. 
To determine the concentration of residual sulfite, $1 \mathrm{~mL}$ sample was added to the tube containing $1 \mathrm{~mL}$ DTNB solution $(1.0 \mathrm{mM}), 1 \mathrm{~mL} \mathrm{NaH} \mathrm{PO}_{4} / \mathrm{Na}_{2} \mathrm{HPO}_{4}$ buffer solution $(\mathrm{pH} 7.0), 1 \mathrm{~mL}$ EDTA solution $(1.0 \mathrm{mM})$ and $6 \mathrm{~mL}$ deionized water. The mixture was allowed to react for 5-10 min and then the absorbance at $412 \mathrm{~nm}$ was measured with a UV-vis spectrometer. ${ }^{2}$

$\mathrm{HOBr}$ generated in $\mathrm{BrO}_{3}{ }^{-}$/sulfite process was analyzed with the bromophenol blue (BPB) method. ${ }^{3}$ In brief, bromination of phenol red generates BPB in the $\mathrm{pH}$ range of 4.6-4.7. The concentration of BPB can be quantified by detecting its absorbance at 592 $\mathrm{nm}\left(\varepsilon=67400 \mathrm{M}^{-1} \mathrm{~cm}^{-1}\right)$. A sample was rapidly transferred into a $25 \mathrm{~mL}$ colorimeter tube containing phenol red (10 $\mu \mathrm{M}$ after mixing) and acetic acid buffer ( $20 \mathrm{mM}$ after mixing) after depleting $\mathrm{HSO}_{3}{ }^{-}$. After 15 min, the absorbance of $\mathrm{BPB}$ was determined at $592 \mathrm{~nm}$.

Electron spin resonance (ESR) spectra were collected with a MiniScope MS-5000 (Magnettech) ESR spectrometer. DMPO (5,5-dimethyl-1-pyrrolidine-N-oxide) was used as the spin-trapping agent in the ESR experiments. $\mathrm{NaHSO}_{3}$ and $\mathrm{DMPO}$ were mixed and then $\mathrm{BrO}_{3}{ }^{-}$was spiked into the mixture for sample of the initial reaction, and $\mathrm{NaHSO}_{3}$ and $\mathrm{BrO}_{3}{ }^{-}$were mixed for 30 min and then DMPO was spiked into the mixture for sample of the reaction process. The samples were transferred quickly to a capillary tube and inserting into the cavity of the spectrometer for analysis. Measurements were carried out under the following conditions: a center field of 3380 Gs, a sweep width of $500 \mathrm{Gs}$, a microwave frequency of $10 \mathrm{~mW}$, a modulation amplitude of $2 \mathrm{Gs}$, and a sweep time of $60 \mathrm{~s}$.

DO was monitored with an oxygen microsensor (OX-25, Unisense A/S) equipped with a one-channel oxygen sensor amplifier (OXY-Meter, Unisense A/S). 
The concentration of formaldehyde was determined with UPLC after derivatization with 2,4-dinitrophenylhydrazine (DNPH). ${ }^{4}$ In a typical procedure, 5.0 $\mathrm{mL}$ of the reaction solution was withdrawn and mixed with $50 \mu \mathrm{L}$ DNPH $(1 \mathrm{~g} / \mathrm{L}$ in $3 \%$ (v/v) phosphate). After reaction for $30 \mathrm{~min}$ at $60^{\circ} \mathrm{C}$, the mixed solution was used for formaldehyde analysis.

The transformation products of phenol by $\mathrm{HOBr}$ alone or $\mathrm{BrO}_{3}{ }^{-} /$sulfite process were identified using GC-MS (GCMS-QP2020, Shimadzu). Before analyzing the transformation products, samples were extracted and desalinated by solid phase extraction (SPE) (Auto Trace 280, Thermo Fisher Scientific) equipped with Poly-Sery HLB cartridge (150 mg, ANPEL, Shanghai) as follows: Firstly, the cartridge was conditioned by $5 \mathrm{~mL}$ methanol and $5 \mathrm{~mL}$ water at a flow rate of $5 \mathrm{~mL} / \mathrm{min}$. Secondly, $500 \mathrm{~mL}$ sample was loaded onto the cartridge at a flow rate of $5 \mathrm{~mL} / \mathrm{min}$ which then dried with $\mathrm{N}_{2}$ gas for 15 min. Finally, the cartridge was rinsed with $10 \mathrm{~mL}$ normal hexane with a flow rate of $3 \mathrm{~mL} / \mathrm{min}$ and the eluted solution was evaporated to $1.5 \mathrm{~mL}$ under a gentle $\mathrm{N}_{2}$ stream.

The details of GC-MS analysis are as follows. A column (Rtx-5 MS, $30 \mathrm{~m} \times 0.25$ $\mathrm{mm} \times 0.25 \mu \mathrm{m}$, Shimadzu) was used for separation. The carrier gas was helium (99.999\%) with a flow rate of $1.5 \mathrm{~mL} / \mathrm{min}$. The temperature program was as follows: initial temperature of $40^{\circ} \mathrm{C}$ held for $10 \mathrm{~min}$, then increased at a rate of $10^{\circ} \mathrm{C} / \mathrm{min}$ to 280 ${ }^{\circ} \mathrm{C}$, and held for $10 \mathrm{~min}$. The injector temperature was $200{ }^{\circ} \mathrm{C}$. The transfer line temperature was $250{ }^{\circ} \mathrm{C}$. The mass detector was set at the following conditions: Operated in the standard electron ionization (EI) mode of $70 \mathrm{eV}$ in the $50-600 \mathrm{amu}$ scan range; the ion source temperature was $230^{\circ} \mathrm{C}$; and the quadrupole temperature was 150 ${ }^{\circ} \mathrm{C}$.

Text S4. Simulating the Transformation Kinetics of Various Species in 


\section{$\mathrm{BrO}_{3}{ }^{-} /$sulfite Process}

A model was built using the Kintecus V6.5 $1^{5}$ chemical kinetic modeling software suite to simulate the kinetics of $\mathrm{BrO}_{3}{ }^{-}$disappearance, $\mathrm{Br}^{-}$generation, as well as phenol and $\mathrm{NB}$ degradation in $\mathrm{BrO}_{3}{ }^{-}$/sulfite system at $\mathrm{pH}_{\text {ini }} 3.0$ in air atmosphere. The initial reaction conditions employed in this model were consistent with those used in experiments. Most of the second-order rate constants $(k)$ for the involved reactions, listed in Table 1, were obtained from literatures. A trial-and-error approach was used to evaluate the unknown rate constants to get the best fitting results. ${ }^{6}$ Similarly, another model was built to simulate the kinetics of $\mathrm{BrO}_{3}{ }^{-}$disappearance and $\mathrm{Br}^{-}$generation in the process of $\mathrm{BrO}_{3}{ }^{-}$reduction by sulfite at $\mathrm{pH}_{\text {ini }} 3.0$ in $\mathrm{N}_{2}$ atmosphere. 


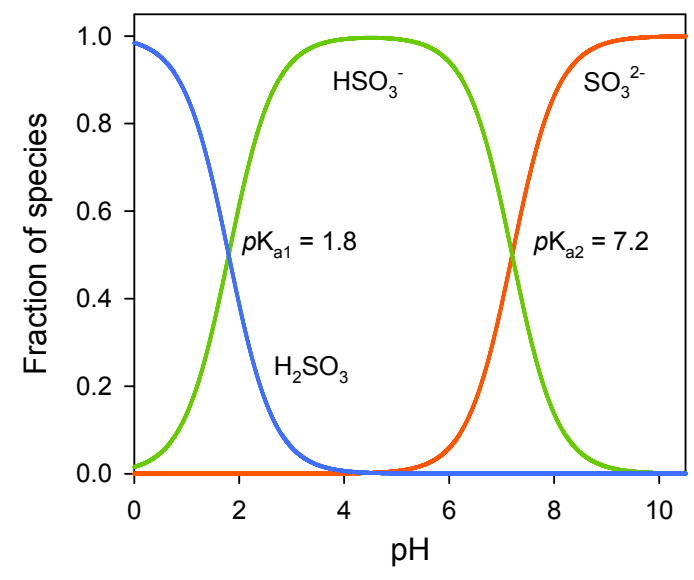

Figure S1. Species distribution of sulfite at various $\mathrm{pH}$ values. 

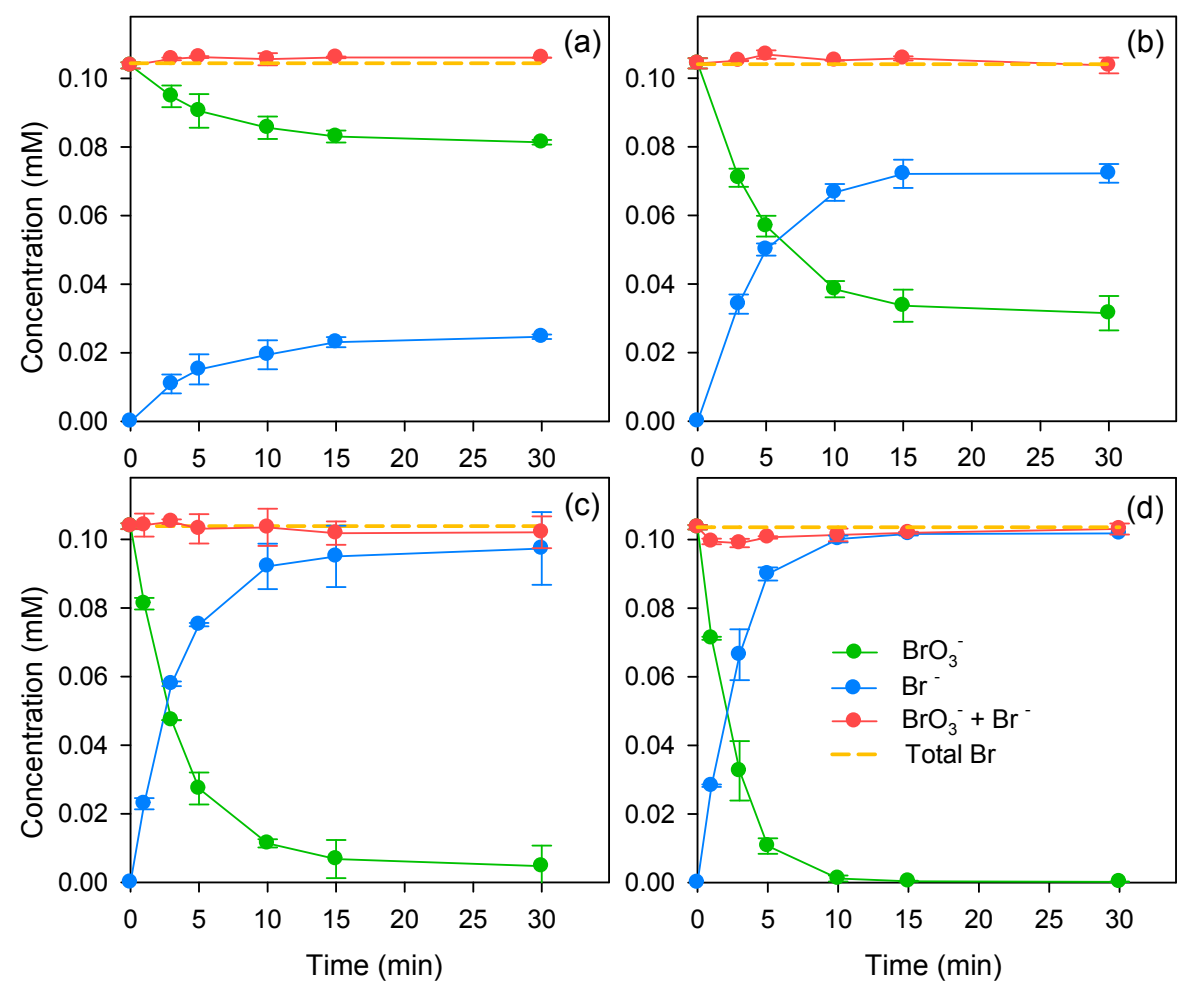

Figure S2. Effect of sulfite dosage on the reduction of $\mathrm{BrO}_{3}{ }^{-}$under oxic conditions.

Reaction conditions: $\mathrm{pH}_{\mathrm{ini}}=4.0,\left[\mathrm{NaBrO}_{3}\right]_{0}=0.1 \mathrm{mM}$, (a) $\left[\mathrm{NaHSO}_{3}\right]_{0}=0.5 \mathrm{mM}$, (b) $\left[\mathrm{NaHSO}_{3}\right]_{0}=1.0 \mathrm{mM}$, (c) $\left[\mathrm{NaHSO}_{3}\right]_{0}=1.5 \mathrm{mM}$, (d) $\left[\mathrm{NaHSO}_{3}\right]_{0}=2.0 \mathrm{mM}$. 

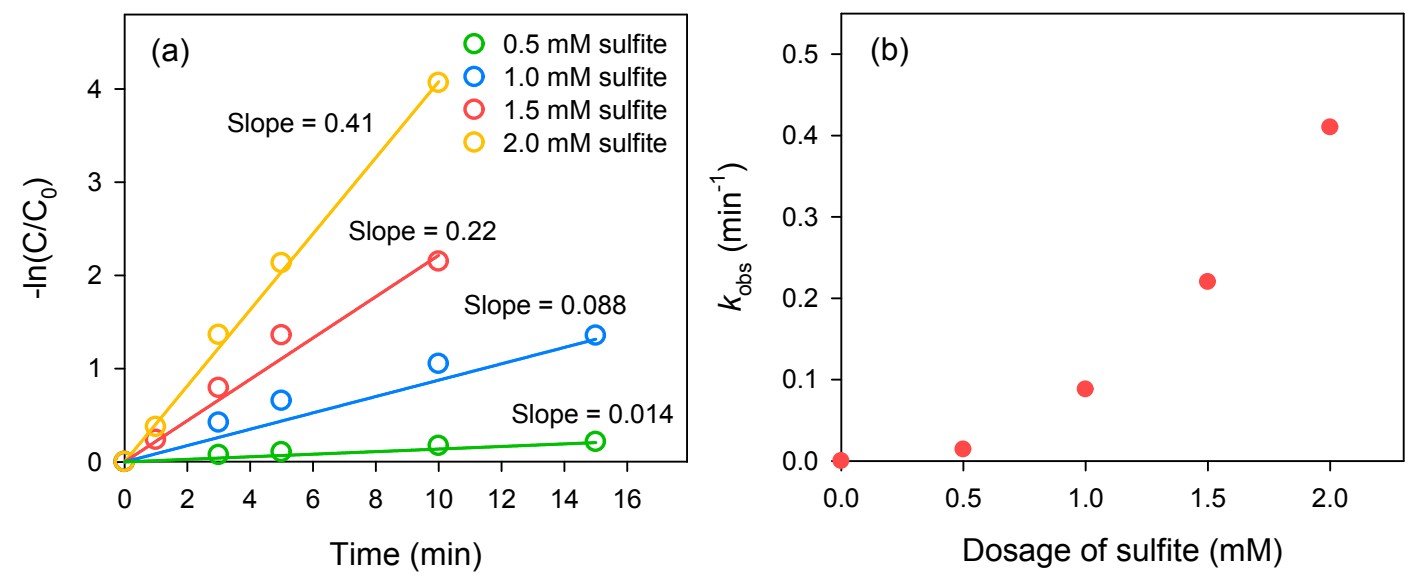

Figure S3. (a) Plot of $-\ln \left(\mathrm{C} / \mathrm{C}_{0}\right)$ vs reaction time at different sulfite dosages; (b) The influence of sulfite dosage on the pseudo-first order rate constant $\left(k_{\mathrm{obs}}\right)$ of $\mathrm{BrO}_{3}^{-}$ reduction at $\mathrm{pH}_{\mathrm{ini}} 4.0$ under oxic conditions. Reaction conditions: $\mathrm{pH}_{\mathrm{ini}}=4.0,\left[\mathrm{NaBrO}_{3}\right]_{0}$ $=0.1 \mathrm{mM},\left[\mathrm{NaHSO}_{3}\right]_{0}=0.5,1.0,1.5,2.0 \mathrm{mM}$. 

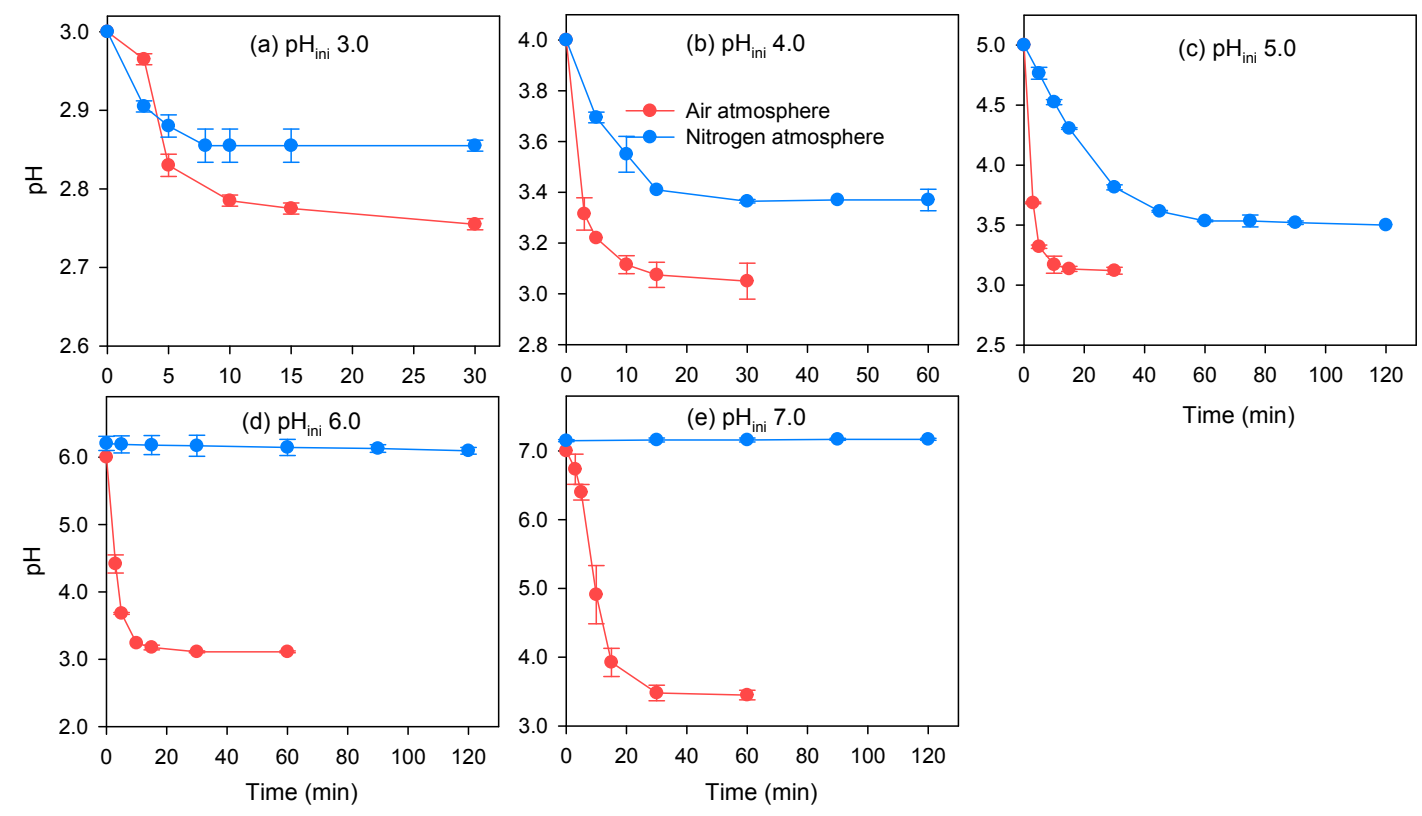

Figure S4. Evolution of $\mathrm{pH}$ during the reduction of $\mathrm{BrO}_{3}^{-}$by sulfite. Reaction conditions: $\left[\mathrm{NaBrO}_{3}\right]_{0}=0.10 \mathrm{mM},\left[\mathrm{NaHSO}_{3}\right]_{0}=1.0 \mathrm{mM}$. 


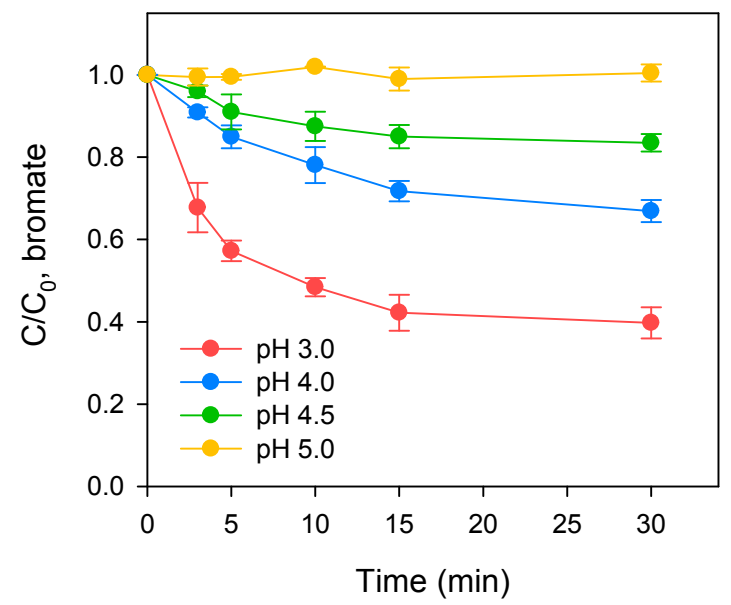

Figure S5. Effect of $\mathrm{pH}$ on the reduction of $\mathrm{BrO}_{3}{ }^{-}$by sulfite when $\mathrm{pH}$ was maintained constant during reaction under oxic conditions. Reaction conditions: $\left[\mathrm{NaBrO}_{3}\right]_{0}=0.10$ $\mathrm{mM},\left[\mathrm{NaHSO}_{3}\right]_{0}=1.0 \mathrm{mM}$. 


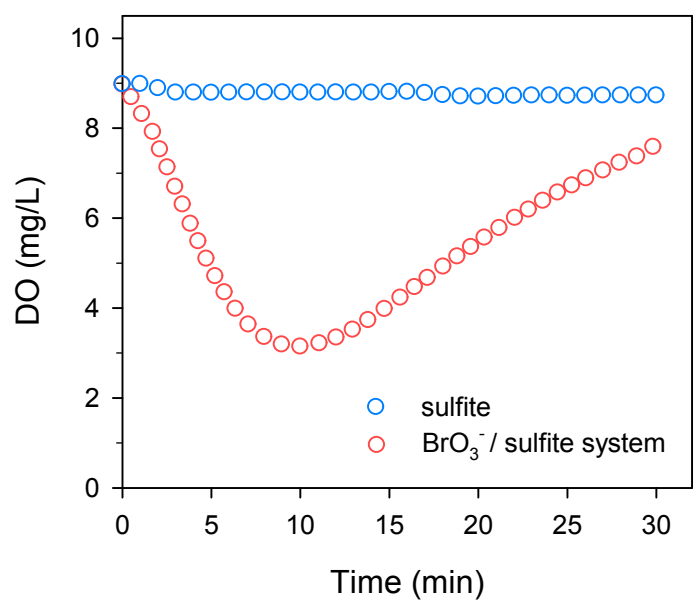

Figure S6. Evolution of DO concentration in $\mathrm{BrO}_{3}{ }^{-} /$sulfite system. Reaction conditions:

$\mathrm{pH}_{\text {ini }}=4.0,\left[\mathrm{NaBrO}_{3}\right]_{0}=0.10 \mathrm{mM},\left[\mathrm{NaHSO}_{3}\right]_{0}=1.0 \mathrm{mM}$. 


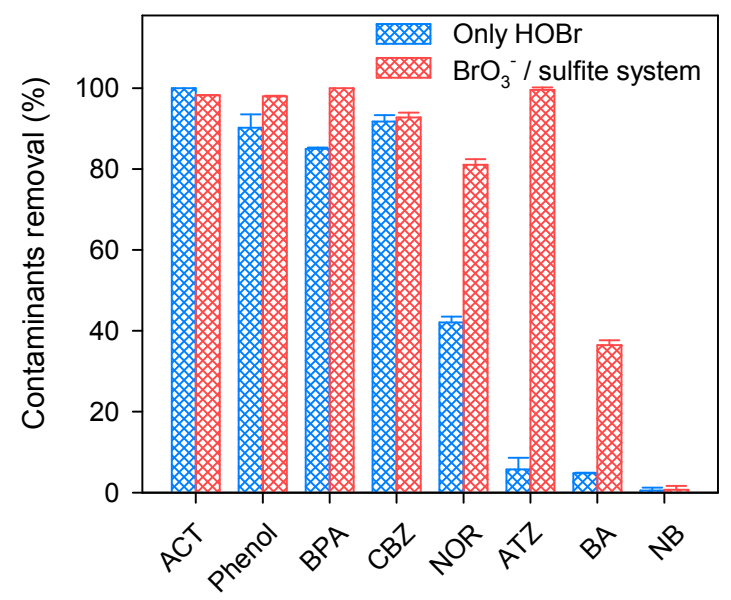

Figure S7. Degradation of contaminants in $\mathrm{HOBr}$ alone and $\mathrm{BrO}_{3}{ }^{-}$sulfite systems under oxic conditions. Reaction conditions: $\mathrm{pH}_{\mathrm{ini}}=4.0,\left[\mathrm{NaBrO}_{3}\right]_{0}=0.10 \mathrm{mM}$, $\left[\mathrm{NaHSO}_{3}\right]_{0}=1.0 \mathrm{mM},[\mathrm{HOBr}]_{0}=10.0 \mu \mathrm{M},[\text { contaminants }]_{0}=10.0 \mu \mathrm{M}$, reaction time $30 \mathrm{~min}$. 


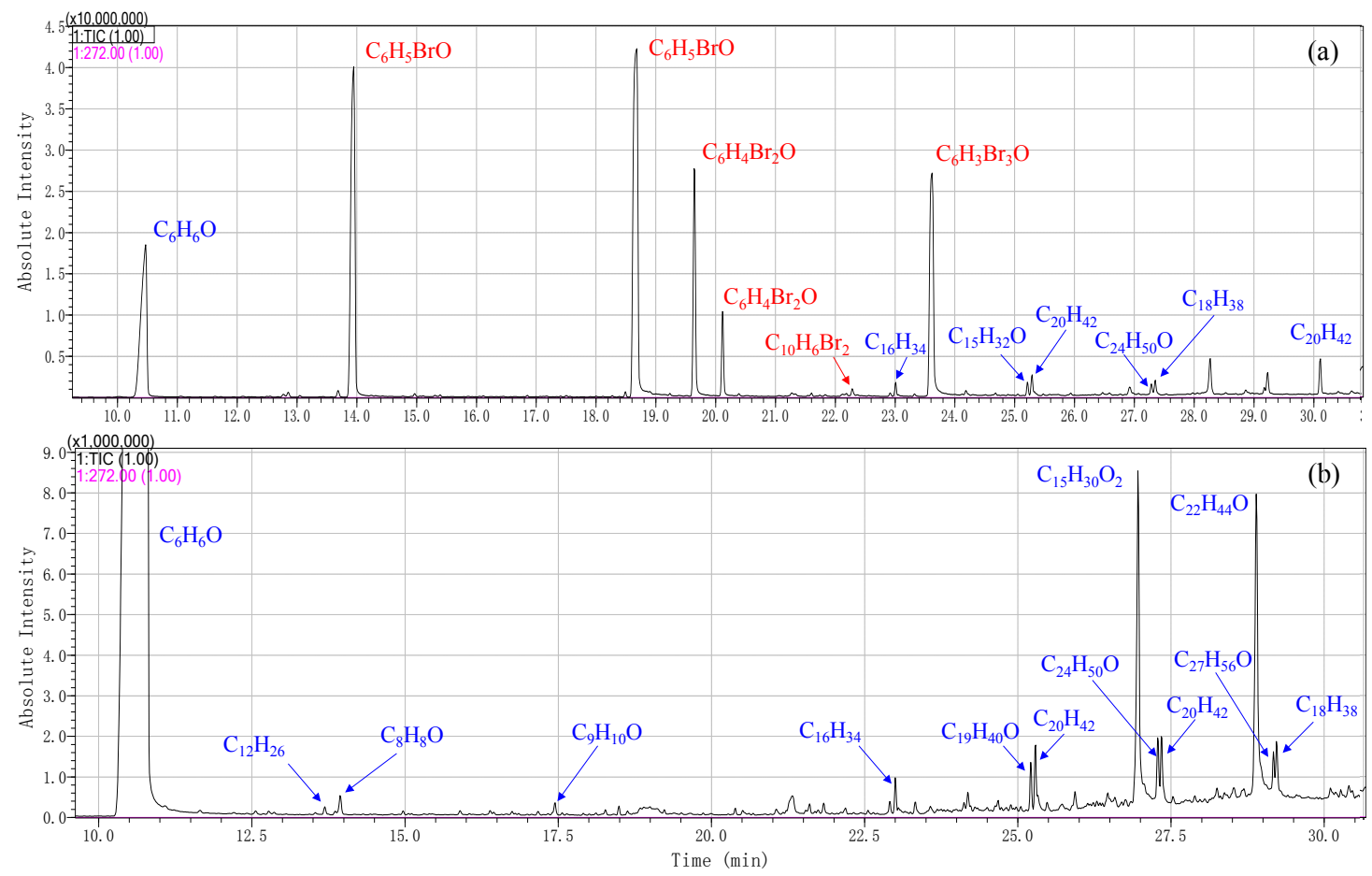

Figure S8. Total ion current chromatograms of phenol after oxidation by $\mathrm{HOBr}$ alone (a) and $\mathrm{BrO}_{3}{ }^{-} /$sulfite systems (b) obtained by GC-MS under oxic conditions. Reaction conditions: $\mathrm{pH}_{\text {ini }}=4.0,[\mathrm{phenol}]_{0}=0.10 \mathrm{mM}$, (a) $[\mathrm{HOBr}]_{0}=0.436 \mathrm{mM}$, (b) $\left[\mathrm{NaBrO}_{3}\right]_{0}$ $=1.0 \mathrm{mM},\left[\mathrm{NaHSO}_{3}\right]_{0}=10.0 \mathrm{mM}$, reaction time $30 \mathrm{~min}$. 


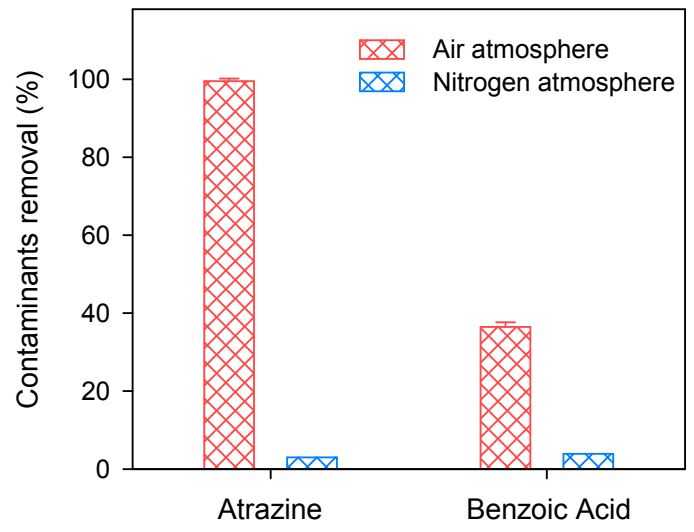

Figure S9. Degradation of atrazine and benzoic acid in $\mathrm{BrO}_{3}{ }^{-} /$sulfite system under oxic or anoxic conditions. Reaction conditions: $\mathrm{pH}_{\mathrm{ini}}=4.0,\left[\mathrm{NaBrO}_{3}\right]_{0}=0.10 \mathrm{mM}$, $\left[\mathrm{NaHSO}_{3}\right]_{0}=1.0 \mathrm{mM}$, [contaminants $]_{0}=10.0 \mu \mathrm{M}$, reaction time $30 \mathrm{~min}$. 

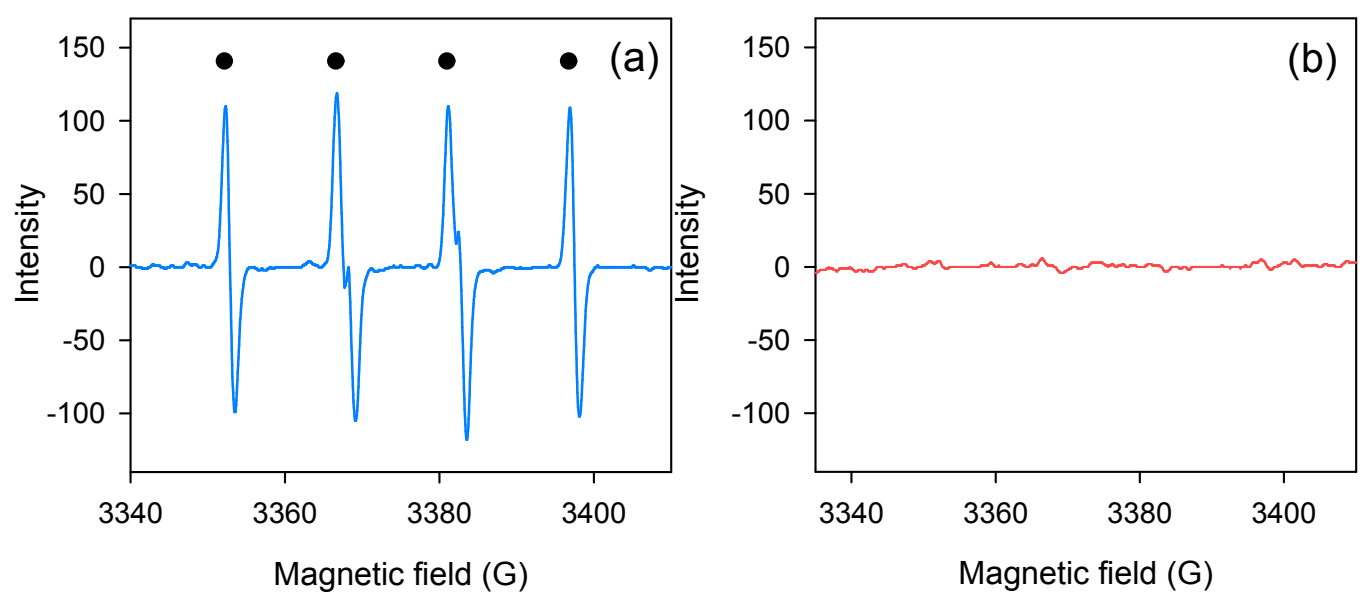

Figure S10. ESR spectrum of DMPO- $\mathrm{SO}_{3}{ }^{--}$at the initial stage of reaction under oxic conditions at pH 2.5 (a) and pH 7.2 (b). Reaction conditions: $\left[\mathrm{NaBrO}_{3}\right]_{0}=0.10 \mathrm{mM}$, $\left[\mathrm{NaHSO}_{3}\right]_{0}=1.0 \mathrm{mM},[\mathrm{DMPO}]_{0}=100 \mathrm{mM}\left(\bullet\right.$ indicates $\mathrm{DMPO}-\mathrm{SO}_{3}{ }^{\cdot-}$ adduct $)$. 


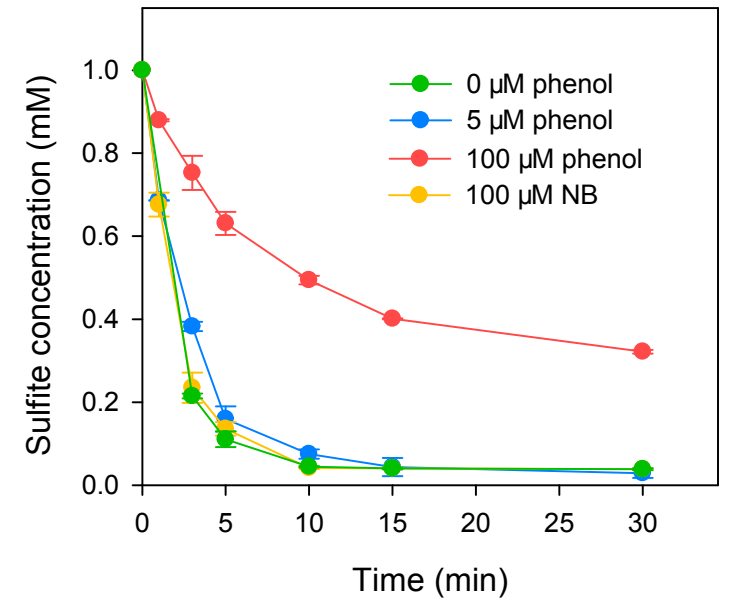

Figure S11. Sulfite consumption in the presence of organic contaminants under oxic conditions. Reaction conditions: $\mathrm{pH}_{\mathrm{ini}}=3.0,\left[\mathrm{NaBrO}_{3}\right]_{0}=0.10 \mathrm{mM},\left[\mathrm{NaHSO}_{3}\right]_{0}=1.0$ $\mathrm{mM}$. 


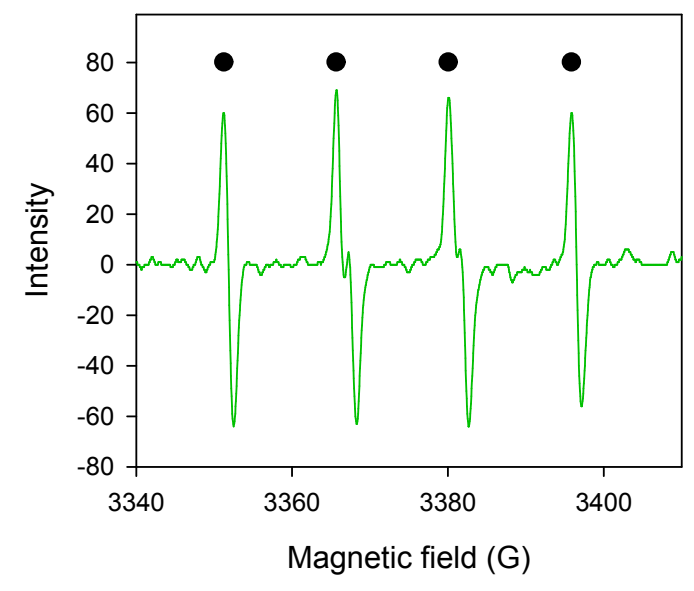

Figure S12. ESR spectrum of DMPO- $\mathrm{SO}_{3}{ }^{\cdot-}$ under anoxic conditions at the initial stage of reaction. Reaction conditions: $\mathrm{pH}_{\mathrm{ini}}=4.0,\left[\mathrm{NaBrO}_{3}\right]_{0}=0.10 \mathrm{mM},\left[\mathrm{NaHSO}_{3}\right]_{0}=1.0$ $\mathrm{mM},[\mathrm{DMPO}]_{0}=100 \mathrm{mM}\left(\bullet\right.$ indicates $\mathrm{DMPO}-\mathrm{SO}_{3}{ }^{\cdot-}$ adduct $)$. 


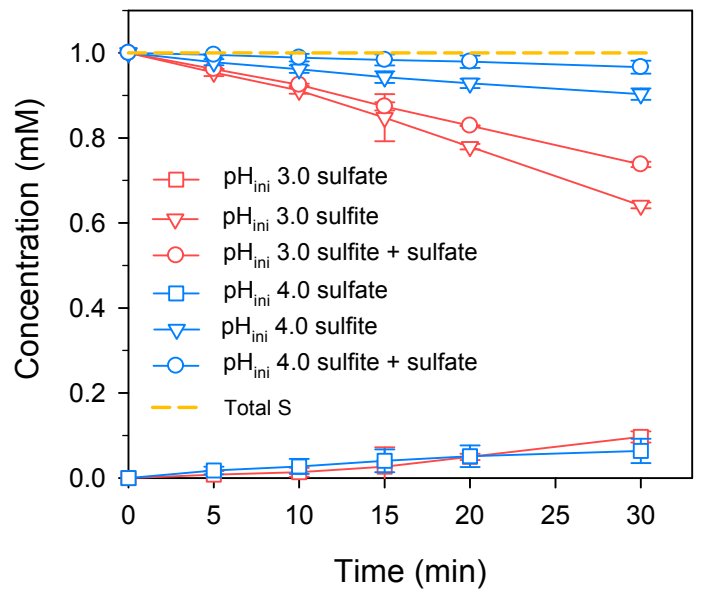

Figure S13. Consumption of sulfite, and generation of sulfate in the open air. Reaction conditions: $\mathrm{pH}_{\mathrm{ini}}=3.0$ or $4.0,\left[\mathrm{NaHSO}_{3}\right]_{0}=1.0 \mathrm{mM}$. 

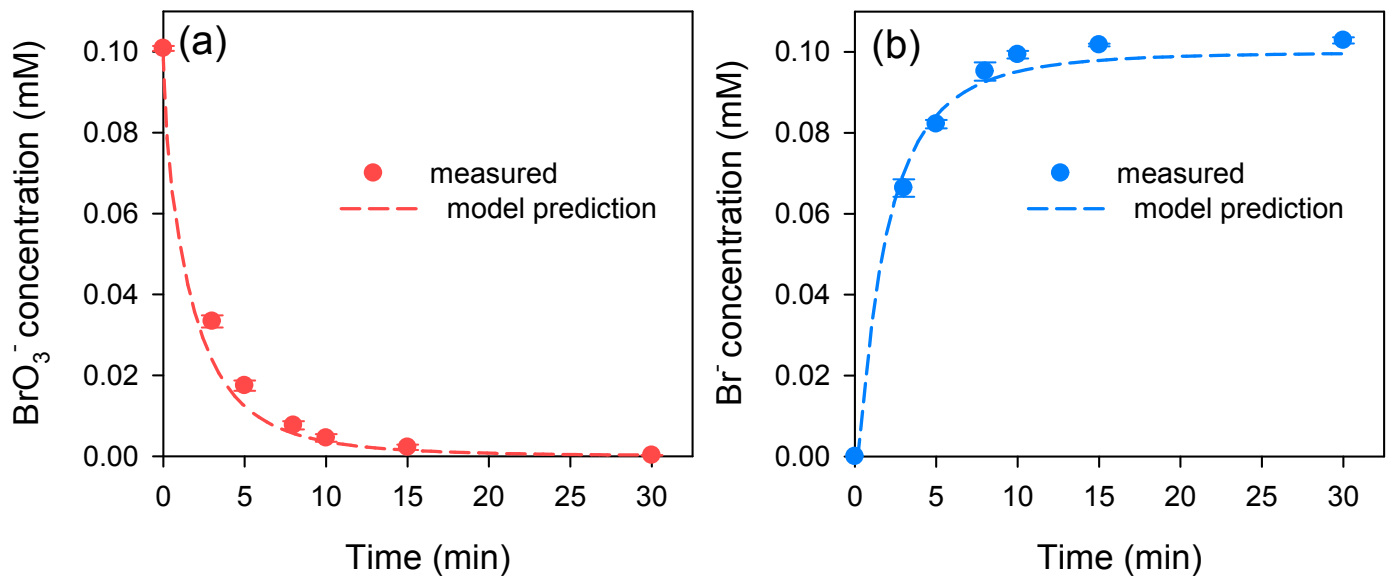

Figure S14. Simulation of $\mathrm{BrO}_{3}{ }^{-}$removal and $\mathrm{Br}^{-}$formation in $\mathrm{BrO}_{3}{ }^{-}$sulfite system under anoxic conditions. Reaction conditions: $\mathrm{pH}_{\mathrm{ini}}=3.0,\left[\mathrm{NaBrO}_{3}\right]_{0}=0.10 \mathrm{mM}$, $\left[\mathrm{NaHSO}_{3}\right]_{0}=1.0 \mathrm{mM}$. 


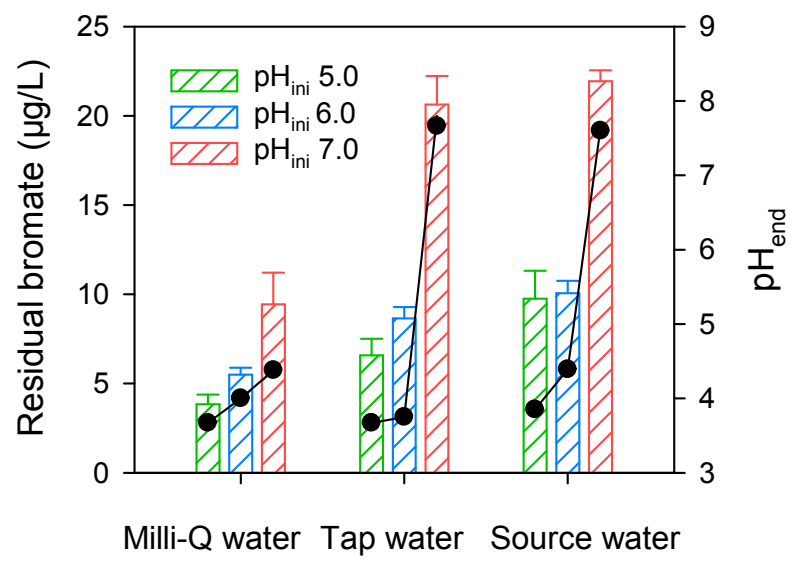

Figure S15. Residual $\mathrm{BrO}_{3}{ }^{-}$after reduction by sulfite at different $\mathrm{pH}_{\text {ini }}$ (bars) in various background water matrices, and the corresponding final $\mathrm{pH}\left(\mathrm{pH}_{\mathrm{end}}\right)$ (solid symbols) under oxic conditions. Reaction conditions: $\left[\mathrm{NaBrO}_{3}\right]_{0}=25.0 \mu \mathrm{g} / \mathrm{L},\left[\mathrm{NaHSO}_{3}\right]_{0}=0.50$ $\mathrm{mM}$, reaction time: $120 \mathrm{~min}$. 
Table S1 UPLC conditions for organic analysis.

\begin{tabular}{cccccccc}
\hline Compounds & $\begin{array}{c}\mathbf{0 . 1 \%} \\
\text { formic } \\
\text { acid (\%) }\end{array}$ & $\begin{array}{c}\text { Acetonitrile } \\
\mathbf{( \% )}\end{array}$ & $\begin{array}{c}\text { Water } \\
\mathbf{( \% )}\end{array}$ & $\begin{array}{c}\text { Methanol } \\
\mathbf{( \% )}\end{array}$ & $\begin{array}{c}\text { Wavelength } \\
\mathbf{( n m )}\end{array}$ & $\begin{array}{c}\text { Flow rate } \\
(\mathbf{m L} / \mathbf{m i n})\end{array}$ & $\begin{array}{c}\text { Retention } \\
\text { time (min) }\end{array}$ \\
\hline phenol & 57 & & & 43 & 273 & 0.16 & 3.4 \\
ACT & 95 & 5 & & & 254 & 0.25 & 3.1 \\
BPA & & & 30 & 70 & 280 & 0.15 & 2.8 \\
CBZ & 40 & & & 60 & 286 & 0.18 & 3.5 \\
ATZ & & & 30 & 70 & 262 & 0.18 & 3.2 \\
BA & 50 & 50 & & & 227 & 0.20 & 1.7 \\
NB & 60 & 40 & & & 262 & 0.25 & 4.0 \\
NOR & 82 & 18 & & & 280 & 0.20 & 6.2 \\
\hline
\end{tabular}


Table S2. The ratios and the rate constants used to calculate them in the quenching experiments.

\begin{tabular}{|c|c|c|c|c|}
\hline $\operatorname{ROS}^{\mathrm{a}}$ & $\mathrm{c}_{1} k_{1} / \mathrm{c}_{2} k_{2}$ & Ratio (\%) & $k\left(\mathrm{M}^{-1} \mathrm{~s}^{-1}\right)$ & Reference \\
\hline \multirow{2}{*}{$\mathrm{HO}^{\bullet}$} & \multirow{2}{*}{$\begin{array}{l}{[\mathrm{phenol}]^{\mathrm{b}} \times k_{\mathrm{HO} ; \text { phenol }} /} \\
{[\mathrm{TBA}]^{\mathrm{c}} \times k_{\mathrm{HO}} ; \mathrm{TBA}}\end{array}$} & \multirow{2}{*}{$\leq 3.47$} & $k_{\mathrm{HO}} ;$ phenol $=6.6 \times 10^{9}$ & 7 \\
\hline & & & $k_{\mathrm{HO} ; \mathrm{TBA}}=3.8 \times 10^{8}-7.6 \times 10^{8}$ & 8 \\
\hline \multirow{3}{*}{$\mathrm{SO}_{4}{ }^{--}$} & \multirow{2}{*}{$\begin{array}{ll}{[\mathrm{TBA}]^{\mathrm{c}} \times k_{\mathrm{SO}_{4}^{--}, \mathrm{TBA}} /} \\
{[\text { phenol }]^{\mathrm{b}} \times k_{\mathrm{SO}_{4}^{--}, \text {phenol }}}\end{array}$} & \multirow[t]{2}{*}{$\leq 5.17$} & $k_{\mathrm{SO}_{4}^{--} \text {,phenol }}=8.8 \times 10^{9}$ & 9 \\
\hline & & & $k_{\mathrm{SO}_{4}^{--}, \mathrm{TBA}}=4.0 \times 10^{5-9.1} \times 10^{5}$ & 10 \\
\hline & $\begin{array}{l}{[\text { phenol }]^{\mathrm{b}} \times k_{\mathrm{SO}_{4}^{--}, \text {phenol }} /} \\
{[\mathrm{EtOH}]^{\mathrm{d}} \times k_{\mathrm{SO}_{4}^{--}, \mathrm{EtoH}}}\end{array}$ & $\leq 5.00$ & $k_{\mathrm{SO}_{4}^{--} \text {,EtOH }}=1.6 \times 10^{7-7.7} \times 10^{7}$ & 10 \\
\hline
\end{tabular}

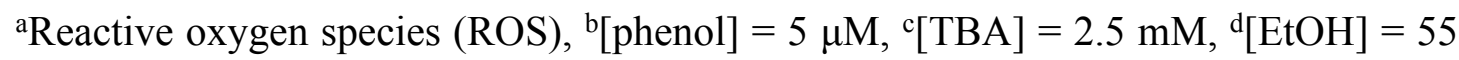
$\mathrm{mM}$. 
Table S3. The model equations and the corresponding rate constants in $\mathrm{N}_{2}$ atmosphere in $\mathrm{BrO}_{3}{ }^{-} /$sulfite system.

\begin{tabular}{llll}
\hline No. & Reaction & $\boldsymbol{k}\left(\mathbf{M}^{-1} \mathbf{s}^{-1}\right)^{\mathbf{b}}$ & Reference \\
\hline R1a & $\mathrm{BrO}_{3}{ }^{-}+\mathrm{H}_{2} \mathrm{SO}_{3} \rightarrow \mathrm{SO}_{3}{ }^{{ }^{-}}+\mathrm{BrO}_{2}+\mathrm{H}_{2} \mathrm{O}$ & 210 & This work \\
R2b & $\mathrm{H}_{2} \mathrm{SO}_{3} \rightarrow \mathrm{SO}_{2}+\mathrm{H}_{2} \mathrm{O}$ & $8.0 \times 10^{-3}$ & This work \\
& & $2.0 \times 10^{8}$, & 11,12 \\
R3c & $\mathrm{HSO}_{3}{ }^{-}+\mathrm{H}^{+} \rightleftharpoons \mathrm{H}_{2} \mathrm{SO}_{3}$ & $3.6 \times 10^{6}$ & \\
& & $3.5 \times 10^{5}$ & This work \\
R4d & $\mathrm{SO}_{3}{ }^{-}+\mathrm{BrO}_{3}{ }^{-} \rightarrow \mathrm{SO}_{4}{ }^{--}+\mathrm{BrO}_{2}$ & $7.5 \times 10^{9}$ & This work \\
R5e & $2 \mathrm{BrO}_{2}+\mathrm{HSO}_{3}{ }^{-}+\mathrm{H}_{2} \mathrm{O} \rightarrow 2 \mathrm{HBrO}_{2}+\mathrm{SO}_{4}{ }^{2-}+\mathrm{H}^{+}$ & $4.2 \times 10^{7}$ & 13 \\
R6f & $2 \mathrm{BrO}_{2}+\mathrm{H}_{2} \mathrm{O} \rightarrow \mathrm{HBrO}_{2}+\mathrm{BrO}_{3}{ }^{-}+\mathrm{H}^{+}$ & $3.0 \times 10^{7}$ & 14 \\
R7g & $\mathrm{HBrO}_{2}+\mathrm{HSO}_{3}{ }^{-} \rightarrow \mathrm{HOBr}^{-} \mathrm{SO}_{4}{ }^{2-}+\mathrm{H}^{+}$ & $1.0 \times 10^{9}$ & 14 \\
R8h & $\mathrm{HOBr}^{+} \mathrm{HSO}_{3}{ }^{-} \rightarrow \mathrm{Br}^{-}+\mathrm{SO}_{4}{ }^{2-}+2 \mathrm{H}^{+}$ & \\
\hline
\end{tabular}

bSome rate constants were obtained from literatures (R3c, and R6f-R8h). The rate constants of R1a-2b, and R4d-R5e were estimated based on fitting the experimental data with the constructed kinetic model under specific conditions.

\section{REFERENCES}

(1) Lahoutifard, N.; Lagrange, P.; Lagrange, J.; Scott, S. L. Kinetics and mechanism of nitrite oxidation by $\mathrm{HOBr} / \mathrm{BrO}^{-}$in atmospheric water and comparison with oxidation by $\mathrm{HOCl} / \mathrm{ClO}^{-}$. J. Phys. Chem. A 2015, 106 (49), 11891-11896.

(2) Humphrey, R. E.; Ward, M. H.; Hinze, W. Spectrophotometric determination of sulfte with 4,4'dithio-dipyridine and 5,5'-dithiobis(2-nitrobenzoic acid). Anal. Chem. 1970, 42, 698-702.

(3) Sollo, F. W.; Larson, T. E.; Mcgurk, F. F. Colorimetric methods for bromine. Environ. Sci. Technol. 1971, 5 (3), 240-246.

(4) Feng, Y.; Lee, P.; Wu, D.; Shih, K. Rapid selective circumneutral degradation of phenolic pollutants using peroxymonosulfate-iodide metal-free oxidation: Role of iodine atoms. Environ. Sci. Technol. 2017, 51 (16), 2312-2320.

(5) Ianni, J. C. Kintecus, Windows Version V6.51, www.kintecus.com. 2017.

(6) Chen, Z.; Li, X.; Zhang, S.; Jin, J.; Song, X.; Wang, X.; Tratnyek, P. G. Overlooked role of peroxides as free radical precursors in advanced oxidation processes. Environ. Sci. Technol. 2019, 53, 2054-2062.

(7) Lindsey, M. E.; Tarr, M. A. Inhibition of hydroxyl radical reaction with aromatics by dissolved natural organic matter. Environ. Sci. Technol. 2000, 34, 444-449.

(8) Buxton, G. V.; Greenstock, C. L.; Helman, W. P.; Ross, A. B. Critical review of rate constants for reactions of hydrated electrons, hydrogen atoms and hydroxyl radicals $\left({ }^{\circ} \mathrm{OH} /{ }^{\circ} \mathrm{O}^{-}\right)$in aqueous solution. J. Phys. Chem. Ref. Data 1988, 17 (2), 513-886.

(9) Ziajka, J.; Pasiuk-Bronikowska, W. Rate constants for atmospheric trace organics scavenging 
$\mathrm{SO}_{4}{ }^{--}$in the Fe-catalysed autoxidation of S (IV). Atmos. Environ. 2005, 39 (8), 1431-1438.

(10) Neta, P.; Huie, R. E.; Ross, A. B. Rate constants for reactions of inorganic radicals in aqueous solution. J. Phys. Chem. Ref. Data 1988, 17, 1027-1284.

(11) Rábai, G.; Hanazaki, I. pH oscillations in the bromate-sulfite-marble semibatch and flow systems. J. Phys. Chem. A 1996, 100, 10615-10619.

(12) Szirovicza, L.; Boga, E. The kinetics of the bromate-sulfite reaction system. Int. J. Chem. Kinet. 1998, 30 (12), 869-874.

(13) Alves, W. A.; Cortes, C. E. S.; Faria, R. B. Formation of high concentrations of $\mathrm{BrO}_{2}$ in acidic bromate solutions. Inorg. Chem. 2004, 43 (14), 4112-4114.

(14) Wang, Z.; Gao, Q.; Pan, C.; Zhao, Y.; Horváth, A. K. Bisulfite-driven autocatalysisin the bromatethiosulfatereaction in a slightly acidic medium. Inorg. Chem. 2012, 51 (22), 12062-12064. 